\title{
Research about Technological Innovation with Deep Civil-Military Integration
}

\author{
Liang JIANG ${ }^{1}$ \\ ${ }^{1}$ Institute of Economics Management Humanities and Social Science \\ Harbin Institute of Technology \\ Harbin, Heilongjiang 150006, China \\ Email:doc1000@163.com
}

\begin{abstract}
This paper not only analyzes characteristics of technological innovation of military enterprises and private enterprises but also discusses the existing problems of technological innovation in the development of deep Civil-Military integration. Furthermore, this paper addresses the issue of realizing technological innovation of enterprises by building market demand system, constructing Enterprises-University-Research institute integration as the main body of collaboration and perfecting long-term advanced technological innovation achievements transformation mechanism.
\end{abstract}

Keywords: Deep Civil-Military Integration; Technological Innovation

\section{Introduction}

With the development of market economy, the pace of economic transition and industry transformation of China is continuously accelerating, which has become invisible and powerful force boosting the development of modern enterprises. Industry transformation refers to the great change of industrial structure of national economy owing to the significant breakthrough in science and technology, which promoting the industrial optimization and upgrading as well as structure modification. Industry transformation is usually originated from innovation of science and technology. At the same time, industry transformation brings about many opportunities and challenges for technological innovation.
Technological innovation is the process of occupying the market share and fulfilling market value by performing technical activities such as applying new knowledge, techniques and processes, introducing new modes of production and business model to improve quality of products, developing and producing new products, offering new services, improving current products, production processes and service modes or creating new products, processes and service modes ${ }^{[1]}$, etc.

Due to the difference of internal and external environment of different enterprises, a single mode of technological innovation does not fit all enterprises. As a consequence, any enterprise is supposed to choose a mode of technological innovation that adapts to the characteristic of enterprise as well as the actual situation to maintain advantages in market competition. With the development modern science and technology, the boundary between military techniques and civilian techniques is becoming more and more blurry. And development of Civil-Military integration has become the new international trend of current world that matches the main theme of peace. According to statistics, $80 \%$ of the techniques utilized in military information construction of US and UK comes from civilian information system ${ }^{[2]}$. Chinese government has also come up with the strategy of development of deep Civil-Military integration. And many researchers and enterprises made a large amount of researches and reforming innovation and obtain some outcomes. However, there are not many researches about technological innovation with deep Civil-Military integration and 
achievements of technological innovation practically obtained. According to the requirements of transforming military products for civilian application, this paper comes up with technological innovation system in the environment of deep Civil-Military integration and realizes technological innovation of enterprises by building market demand orientation, constructing Enterprises-University-Research institute integration as the main body of collaboration and perfecting long-term advanced technological innovation achievements transformation mechanism.

\section{System and characteristics of technological innovation of enterprises}

\subsection{System and characteristics of technological innovation of military enterprises}

Military enterprises shoulder the important responsibility of developing national defense industry. And a relatively stable system of technological innovation has formed for many years. In the system, military enterprises are the main body in realization of technological innovation. Military departments are responsible for raising the demand to military enterprises in related field and providing them with funding guarantee. The main evaluation mode of technological innovation includes industry experts assessment and inspection before delivery.

Specific characteristics of technological innovation of military enterprises are listed below:

1) Technological innovation is mainly driven by demands of the military with specific purpose and schedule. A new technique or product is produced by conducting the plan in accordance with the mid or long term development strategies, which is mainly formulated based on the technical characteristics of their own and national development policies. According to the requirements of the military, development processes proceed as the related research and production procedures specified by the military. And there are strict rules and procedures which ensure quality of products in every stage of producing a new product from basic research, pre-research, project feasibility argumentation, presentation and verification to engineering prototyping, mass production, maintenance and support. However, military enterprises react slowly to the diversified market and are less sensitive to new technologies in comparison with private enterprises due to overreliance on the demands and procurement plan of the military.

2) Military enterprises have sufficient research and development resources as well as abundant fund, talents and equipment, which can meet the requirements of developing large-scale research. So they have distinct advantages on resource support.

3) Military enterprises have a higher degree of innovation in production. After innovative new concepts becoming products, there are many problems about innovation in processes, performance and quality improvement. Regarding to this aspect, military enterprises have sophisticated system of research and production management as well as system of quality management, which can ensure the production, quality improvement of products and development of process techniques.

4) Leading position and lacking of necessary competition in a certain industry leads to deficiency of innovation energy and revolutionary innovation. And they put more focus on improvement of current techniques.

\subsection{System and characteristics of technological innovation of private enterprises}

As an important part of economic development, private enterprises have made great contribution to economic development. Surviving in market competition has become the motivation of technological innovation for private enterprises. And they can seek for more market share via technological innovation. As a consequence, input of technological innovation is the demand of market. And their funding support usually comes from financing, loan or their own funding. And the main body of innovation is the enterprise itself. But the system of evaluating technological innovation takes the market share transferred from innovation as the criteria of evaluation. Therefore, private enterprises mainly develop short cycle technological innovation due to pressure of market competition and fund. 
Specific characteristics of technological innovation of private enterprises are listed below:

1) Technological innovation of private enterprises is mainly market-oriented and consumer-oriented. And they introduce product innovation, processes innovation, research and development, transformation and any method possible to produce various innovation outcomes. And the origin, mode and outcome of innovation all exhibits versatility to some extent.

2) Organization structure is relatively simple that can incorporate internal resources rapidly into the process of innovation, shortening the process of innovation. However, pressure of market competition, relative deficiency of human resources and funding support and relatively backward production processes limit the capability of innovation.

3) Private enterprises are sensitive to market, make decisions quickly and have flexible modes of development. And they can apply new technique outcomes to producing new products more quickly that will help them to occupy the market in advance.

\section{Problems of technological innovation under deep collaboration between military enterprises and private enterprises}

Civil-Military integration refers to integrating national defense and modernization construction of PLA into national economic society development system in a wider range, higher level and bigger depth. Technological innovation under Civil-Military integration refers to applying military techniques and civilian techniques together to producing new products and new processes guided by market in 2 fields, and applying to market in series to realize development of deep Civil-Military integration.

In the process of development of Civil-Military integration, many countries in the world have made progress. But there are still some problems that cannot be ignored at the same time due to the natural differences between military enterprises and private enterprises. First, they serve different market customers. When transfer between military application and civilian application is conducted, the outstanding problem is that the research outcome and market demands don't match with each other. Military enterprises have long been working on research and production of military equipment and their products development is discussed mainly based on the demand of the military and equipment plan. So they focused on function and performance in military deeds. And we found that advantages of military technology do not match with the requirements of civilian products when marketed in civilian market where technological content of products keeps changing as demands of market changes. While private enterprises serves consumers and focused on using effects of the products including economic efficiency, appearance, comfortableness, practicability and etc. And their products index may not satisfy the military requirements for battle. Second, their operation conditions are different. Products produced by military enterprises are requested to operate in harsh environment with high temperature, low temperature, high interference and etc. But civilian market concerns more about completing certain missions and has no strict requirements for index and operating in critical boundary conditions. Third, their development of products refers to different standards. Products development of military enterprises proceeds according to the standards and regulations defined in weaponry and equipment development and production management rules, forming a system of specialized standards. So for private enterprises attempting to enter military products market, being up to related standards and regulations is a must. Last but not least, private enterprises are limited by military products development qualifications. Military enterprises have a whole set of military products development certificate of qualifications. So obtaining corresponding qualifications is the prerequisite of entering military products market for private enterprises.

In this situation, direct integration of military and civilian market, direct transformation between military and civilian techniques and direct trade of military and civilian products will surely cause the phenomenon of not matching, which will restrict development of deep Civil-Military integration. 
Therefore, in order to truly develop under deep integration, enterprises have to integrate technological innovations to every stage of development from market investigation and scheme discussion at the beginning of product design, scheme design and functional realization in the design process to production configuration and marketing.

\section{Thinking pattern of resolutions to technological innovation with Civil-Military integration}

\subsection{Building market-orientated system of technological innovation}

Dr. Myers and Marquls from MIT in US conducted an important demonstration job in 1969. They made a sample survey among 567 projects of innovative techniques in 5 industries and they found that $3 / 4$ of the technological innovation is market-oriented and $1 / 4$ of the technological innovation originated from development of techniques themselves ${ }^{[3]}$. As a result, technological innovation comes from market demands and the principal task to achieve Civil-Military integration is to build a market-oriented system of technological innovation.

First, enterprises should divide market with different domains, specify demands of different market and build a refined customer relationship management system. They will find the entry point of technological innovation with Civil-military integration to enter the corresponding market according to market characteristics based on their own technical advantages. Second, enterprises should realize the transition gradually from the simplified market and products to versatile and serialized product system. And they should determine the technical content of a product in terms of different customers, different demands, different application and different market price position, and eventually form serialized products system to accommodate different market demands with products in high, mid and low level.

\subsection{Constructing Enterprises-University-Research institute integration as the main body of technological innovation collaboration}

Applying Enterprise-University-Research Institute cooperation to unified innovation can make full use of advantages of enterprises, research institutes and universities. In order to accommodate market demands and technique demands, we should actively explore new techniques, overcome technical difficulties and develop techniques with independent intellectual property rights via resources integration, independent research, cooperative development, technique transfer and etc. in face of military and civilian market. And commercialization and industrialization of techniques will further help to obtain advantages in fierce market competition. Enterprises as the main body of technological innovation can integrate resources with high efficiency based on market demands and provide products with latest techniques rapidly to accommodate market demands. Universities and research institutes as the fresh force of technological innovation mainly take advantages of talents, professions and techniques. And they can provide enterprises with direct support of talents and techniques by cooperating with enterprises closely based on demands of military market. Via cooperative research, they offered corresponding pre-research outcome, technique outcome and development outcome of new products. This is the implementation method of technological innovation with development of deep Civil-Military integration.

\subsection{Considering factors of Civil-Military integration from the initial phase of design}

Factors of Civil-Military integration should be taken into consideration in market investigation and scheme discussion at the initial phase of design for following development of deep Civil-Military integration and sustainable development. Enterprises should make technical feasibility analysis, economic cost analysis and risk analysis for products and techniques that can be transformed to different market with different market outlook by investigating different market based on current technical 
capabilities and product systems of their own. And we can also adopt one of following modes of development including Civil-Military researching and producing simultaneously, military enterprises ahead or private enterprises ahead depending on development mode of a company's main business. By considering a single technique transformed and utilized in multiple market, utilization of innovative techniques and enterprises profitability are dramatically improved. This is the implementation method of technological innovation with development of deep Civil-Military integration.

\subsection{Improve the long-term transformation mechanism of} advanced technological innovation achievement

In the development of technologies, the life cycle of the study for long-term transformation of advanced technological innovation achievement is long. Besides, there is a comparatively large in financial stress for enterprises. The motivation of innovation is relatively weak. However, it is essential to transform the technical achievement. It is necessary to perfect the long-term transformation mechanism of advanced technological innovation achievement. We must provide research budget for the technological innovation project to enhance enterprises enthusiasm and reduce enterprises funding risk.

\section{Conclusions}

Science and technology are the primary productive force. Currently, under the megatrends of development of deep Civil-Military integration, enterprises should appreciate the effect of technological innovation on the way of seeking for self-development. This paper innovatively comes up with the idea of sticking to market-oriented strategies, constructing Enterprises-University-Research institute integration as the main body of collaboration, considering factors of Civil-Military integration from initial phase of design and perfecting long-term advanced technological innovation achievements transformation mechanism to realize development of deep Civil-Military integration.

\section{References}

[1] Jiang Zengjin, "Discussion about Technological Innovation and Development of Middle and Small Enterprises," China Science and Technology Information, pp. 198-201, 2014.

[2] Guo Shangfen, "Study on Constructing Coordinated Innovation Mechanism for Military and Civilian Integration," Science \& Technology Progress and Policy, pp. 95-97, 2014.

[3] E. Mansfield, "Industrial Innovation in Japan and the United States," Science, pp. 49-61, 1988. 